\title{
Oxidative Stress-Associated Pathology: A Review
}

(Patologi berkaitan Tekanan Oksidatif: Suatu Kajian)

\author{
SARAWOOT PALIPOCH* \& PHANIT KOOMHIN
}

\begin{abstract}
Currently, oxidative stress (OS) has become a major interest in point of basic science and clinical research. The imbalance between generations and clearances of oxidants leads to os. Oxidants are mainly composed of reactive oxygen species (ROS) and reactive nitrogen species (RNS) which are manifested as oxidized macromolecules causing deleterious effects in several organs. Lipid, protein and DNA oxidation products can provide extensively approach of potential oxidative stress biomarkers. Os leads to the fundamental cellular and tissue damages and consequence effect to various organs or systems. This review emphasizes the systemic pathology induced by os that particularly affect to specialized organs or systems including the nervous system, the cardiovascular system, the lung, the liver and the kidney.
\end{abstract}

Keywords: Oxidative stress; reactive nitrogen species; reactive oxygen species

ABSTRAK

Dewasa ini, tekanan oksidatif (OS) telah menjadi salah satu kajian yang menarik perhatian dalam sains asas dan penyelidikan klinikal. Ketidakseimbangan antara generasi dan kelegaan oksida membawa kepada os. Oksidan terutamanya terdiri daripada spesies reaktif oksigen (ROS) dan spesies nitrogen reaktif (RNS) yang dimanifestasikan sebagai makromolekul teroksida menyebabkan kesan yang merosakkan ke dalam beberapa organ-organ. Lipid, protein dan produk pengoksidaan DNA boleh memberikan pendekatan menyeluruh potensi penanda biologi tekanan oksidatif. os boleh membawa kepada kerosakan sel dan tisu dan memberi kesan kepada pelbagai organ atau sistem. Kajian ini menekankan patologi sistemik yang disebabkan oleh os terutamanya memberi kesan kepada organ atau sistem khusus termasuk sistem saraf, sistem kardiovaskular, paru-paru, hati dan buah pinggang.

Kata kunci: Spesies nitrogen reaktif; spesies oksigen reaktif; tekanan oksidatif

\section{INTRODUCTION}

Oxidative stress (OS) has increasingly become a major interested point of basic science and clinical research. OS is conceptually defined as the imbalance between generations and clearances of oxidants (Figure 1). As shown in Table 1, oxidants are composed of reactive freeradical and radical including reactive oxygen species (ROS) and reactive nitrogen species (RNS) which are manifested by several macromolecules especially lipid, protein and DNA causing deleterious effects in several organs (Arnouk et al. 2011; Bhimaraj \& Tang 2012; Brzóska et al. 2011; Matsubara et al. 2015; Rác et al. 2015). Ros are composed of superoxide radical $\left(\mathrm{O}_{2}^{-}\right)$, hydroxyl radical $\left({ }^{\circ} \mathrm{OH}\right)$, hydrogen peroxide $\left(\mathrm{H}_{2} \mathrm{O}_{2}\right)$, peroxyl radical $\left(\mathrm{RO}_{2}{ }^{\circ}\right)$, alkoxyl radical ( $\left.\mathrm{RO}^{\circ}\right)$, hydroperoxyl radical $\left(\mathrm{HO}_{2}{ }^{\circ}\right)$, singlet oxygen and ozone. RNS include nitric oxide ( $\left.{ }^{\circ} \mathrm{NO}\right)$, nitrogen dioxide $\left({ }^{-} \mathrm{NO}_{2}\right)$, nitrous acid $\left(\mathrm{HNO}_{2}\right)$, dinitrogen tetroxide $\left(\mathrm{N}_{2} \mathrm{O}_{4}\right)$, dinitrogen trioxide $\left(\mathrm{N}_{2} \mathrm{O}_{3}\right)$, peroxynitrite $(\mathrm{ONOO})^{\circ}$ ), peroxynitrous acid (ONOOH), alkyl peroxynitrites (ROONO) and nitryl chloride $\left(\mathrm{NO}_{2} \mathrm{Cl}\right)$. Oxidizing agents can be produced by both endogenous source (inflammatory cells, fibroblast, epithelial cells, endothelial cells, respiratory chain, xanthine and NADPH oxidase) and exogenous source (cigarette smoke, exogenous toxins, pollution, radiation, carcinogens and drugs) (Bargagli et al. 2009; Choi et al. 2014; Nomura et al. 2014; Nourazarian et al. 2014). Under normal physiological condition, oxidants are removed through antioxidant defense mechanism. If incompletely cleared by antioxidants, oxidants will caused accumulation of OS. Inefficiency and insufficiency of antioxidant defense system are concerned in some pathological conditions induced by OS (Gao et al. 2009; Luchese et al. 2009; Mathy-Hartert et al. 2008; Palipoch 2013; Palipoch \& Punsawad 2013).

As shown in Figure 2, risk factors which are related to os-induced pathologies include alcohol consumption, cigarette smoking, diet, gender, geographic location specifically at high altitude and occupation. Alcohol metabolism is linked to ROS/RNS generations leading increased oxidative stress biomarkers such as malondialdehyde (MDA) and 4-hydroxynonenal (HNE) and decreased antioxidative defense systems (Das \& Vasudevan 2007; Kim et al. 2015). Cigarette smoking causes injury to the cardiovascular, pulmonary and other OS related diseases including infertility in men (Elshal et al. 2009; Kim et al. 2014; Lee et al. 2015; Saleh et al. 2002). Consumption of high fat diet causes os through overproduction of ROS resulting in hepatic oxidative 
(A) Normal condition

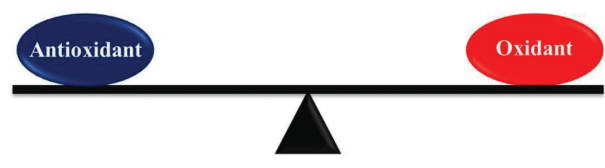

(B) Oxidative stress

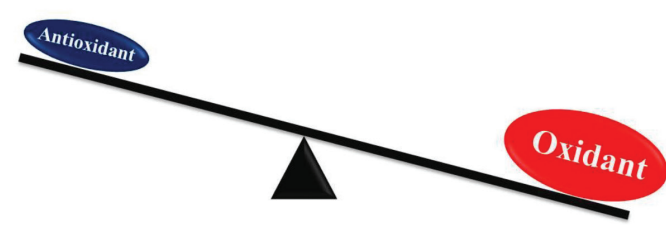

FIGURE 1. General concept of oxidative stress (a) Normal condition is indicated the balance between oxidant production and antioxidant defense system and (b) OS is demonstrated the imbalance between generation and clearance of oxidant

TABLE 1. Main reactive oxygen species and reactive nitrogen species

(Bargagli et al. 2009)

\begin{tabular}{ll}
\hline Reactive oxygen species (ROS) & Reactive nitrogen species (RNS) \\
\hline Superoxide radical $\left(\mathrm{O}_{2}^{\cdot}\right)$ & Nitric oxide $\left({ }^{\circ} \mathrm{NO}\right)$ \\
Hydroxyl radical $\left({ }^{\circ} \mathrm{OH}\right)$ & Nitrogen dioxide $\left({ }^{\circ} \mathrm{NO}_{2}\right)$ \\
Hydrogen peroxide $\left(\mathrm{H}_{2} \mathrm{O}_{2}\right)$ & Nitrous acid $\left(\mathrm{HNO}_{2}\right)$ \\
Peroxyl radical $\left(\mathrm{RO}_{2}^{\cdot}\right)$ & Dinitrogen tetroxide $\left(\mathrm{N}_{2} \mathrm{O}_{4}\right)$ \\
Alkoxyl radical $\left(\mathrm{RO}^{\cdot}\right)$ & Dinitrogen trioxide $\left(\mathrm{N}_{2} \mathrm{O}_{3}\right)$ \\
Hydroperoxyl radical $\left(\mathrm{HO}_{2} \cdot\right)$ & Peroxynitrite $(\mathrm{ONOO} \cdot)$ \\
Singlet oxygen & Peroxynitrous acid $(\mathrm{ONOOH})$ \\
& Alkyl peroxynitrites $(\mathrm{ROONO})$ \\
& Nitryl chloride $\left(\mathrm{NO}_{2} \mathrm{Cl}\right)$ \\
\hline
\end{tabular}

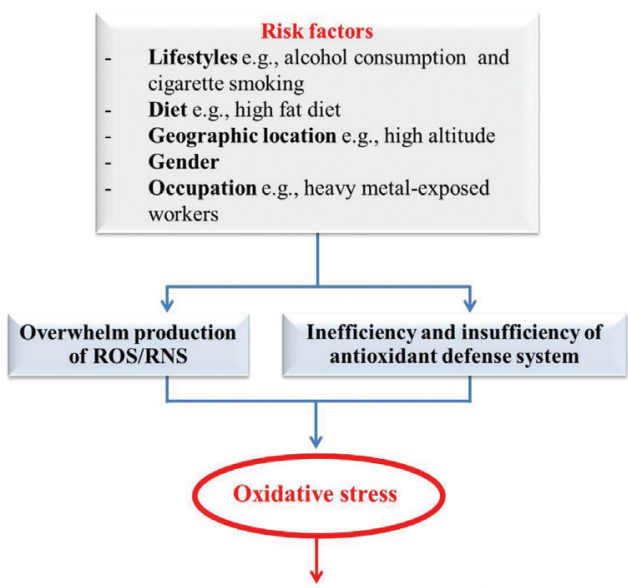

Systemic pathology

FIGURE 2. Risk factors related with OS-induced pathologies

damage, thus antioxidant supplementations are good beneficial choices (Feillet-Coudray et al. 2009; Yang et al. 2008). Gender differences in OS are shown in several diseases such as coronary artery disease (Vassalle et al.
2008) and hypertension (Ward et al. 2004). Exposure to high altitude causes hypoxia which is associated with OS and resembles ischemia/reperfusion injury by either increased ROS/RNS production or weak antioxidant defense 
system (Dosek et al. 2007; Lundby et al. 2003). In addition, workers who are exposed to heavy metals demonstrated increased OS in their system (Gurer-Orhan et al. 2004).

\section{OXIDATIVE STRESS BIOMARKERS}

Oxidative stress biomarkers are the measurable biologically produced change in the body connected with pathology induced by OS (Table 2). Lipid, protein and DNA oxidation products provide extensively approach of potential biomarkers (Blumberg 2004; Kurutas et al. 2015; Zhong \& Yin 2014). Currently, lots of methods exist that potentially allow the measurement of oxidative stress status in the blood, plasma and urine (Blumberg 2004; Kadiiska et al. 2011, 2005; Kurutas et al. 2015; Parker et al. 2001). Lipid peroxidation (LPO) is demonstrated to induce disturbance of membrane function and integrity and modification of proteins and DNA bases which has been implicated in the pathogenesis of various diseases (Dzięgielewska-Gęsiak et al. 2014; Etsuo 2009). Polyunsaturated fatty acids are especially susceptible to oxidation and readily form lipid hydroperoxides which ultimately give rise to $\alpha, \beta$ unsaturated aldehydes and other LPO products. These aldehyde species exhibit toxicity by covalently modifying nucleophilic moieties of proteins and DNA. MDA and HNE are the most potential biomarkers of LPO (Ayala et al. 2014; Sowell et al.2005). MDA is the stable end product from the oxidative degradation of polyunsaturated fatty acids (Ayala et al. 2014; Horton \& Fairhurst 1987) which are usually correlated with the pathogenesis of various diseases such as atherosclerosis, stroke and Graves' disease (Cherubini et al. 2005; Duryee et al. 2010; Guerra et al. 2005; Kirisattayakul et al. 2013; Wang et al. 2014). A second toxic messenger of oxygen free radicals, HNE is the major aldehyde formed as consequence of the oxidation of $n-6$ unsaturated fatty acids (Esterbauer et al. 1991) that is related to various pathological conditions including age-related macular degeneration (Kaarniranta et al. 2005), stroke (Cherubini et al. 2005) and liver diseases (Poli et al. 2008). Other LPO potential biomarker is a complex family of compounds produced from arachidonic acid, F2-isoprostanes which provide a strong link to diseases associated with ischemiareperfusion, atherosclerosis and inflammation (Cracowski et al. 2002; Ishii et al. 2010). Urinary excretions of 8 -isoprostane-F2 $\alpha$ were significantly higher in children with oxidative stress-related autism (Ming et al. 2005). Oxidative damage to proteins especially susceptible amino acid such as lysine, proline and threonine may results in protein-bound carbonyl structures which are often associated with protein denaturation, reduced solubility and loss of biological function (Mehlhase \& Grune 2002; Stadtman \& Levine 2003, 2000). These protein carbonyls can be used as a representative biomarker of the protein oxidation. During LPO, carbonyl groups may be introduced into proteins by secondary reaction of aldehydes such as MDA and HNE with nucleophilic side chains of amino acids including cysteine, histidine and lysine (Dalle-Donne et al. 2003). In addition, reactive carbonyl derivatives such as ketoamines and deoxyosones can be affected by amino residues with consequence of glycoxidation and lipoxidation products (Stadtman \& Berlett 1997). Protein oxidation products are related with various OS-induced pathologies including chronic periodontitis (Baltacıoğlu et al. 2008), familial hypercholesterolemia (Pirinccioglu et al. 2010), acute pancreatitis (Winterbourn et al. 2003), Alzheimer's disease (Korolainen et al. 2006), multiple sclerosis (Miller et al. 2012) and myocardial infarction (Paton et al.2010). The level of oxidized DNA damage has

TABLE 2. Oxidative stress biomarkers and OS-related diseases

\begin{tabular}{|c|c|c|c|}
\hline Biomarkers & Targets of oxidation & Examples of OS-related diseases & References \\
\hline $\begin{array}{l}\text { 8-hydroxy-2'- } \\
\text { deoxyguanosine } \\
\text { (8-OHdG) }\end{array}$ & DNA & $\begin{array}{l}\text { Parkinson's disease, rheumatoid } \\
\text { arthritis, cancer, atherosclerosis and } \\
\text { diabetics }\end{array}$ & $\begin{array}{l}\text { (Dong et al. 2015; Kuo et al. 2007; Rall } \\
\text { et al. 2000; Wu et al. 2004; Yasuhara et } \\
\text { al. 2007) }\end{array}$ \\
\hline $\begin{array}{l}\text { 8-oxo- } 7,8- \\
\text { dihydroguanine } \\
\text { (8-oxoGua) }\end{array}$ & DNA & $\begin{array}{l}\text { Cancer, Alzheimer's disease, aging } \\
\text { and neurodegenerative diseases }\end{array}$ & $\begin{array}{l}\text { (Eiberger et al. 2008; Moreira et al. } \\
\text { 2008; Protano et al. 2014; Radak et al. } \\
\text { 2011) }\end{array}$ \\
\hline $\begin{array}{l}\text { Malondialdehyde } \\
\text { (MDA) }\end{array}$ & $\begin{array}{l}\text { Polyunsaturated } \\
\text { fatty acids }\end{array}$ & $\begin{array}{l}\text { Atherosclerosis, stroke and Graves' } \\
\text { disease }\end{array}$ & $\begin{array}{l}\text { (Cherubini et al. 2005; Duryee et al. } \\
\text { 2010; Guerra et al. 2005; Yoon et al. } \\
\text { 2015) }\end{array}$ \\
\hline $\begin{array}{l}\text { 4-hydroxynonenal } \\
\text { (HNE) }\end{array}$ & $\begin{array}{l}n-6 \text { unsaturated } \\
\text { fatty acids }\end{array}$ & $\begin{array}{l}\text { Age-related macular degeneration, } \\
\text { stroke and liver diseases }\end{array}$ & $\begin{array}{l}\text { (Cherubini et al. 2005; Kaarniranta et al. } \\
\text { 2005; Poli et al. 2008; Yang et al. 2014) }\end{array}$ \\
\hline F2-isoprostanes & Arachidonic acid & $\begin{array}{l}\text { Ischemia-reperfusion, atherosclerosis } \\
\text { and inflammation }\end{array}$ & $\begin{array}{l}\text { (Cracowski et al. 2002; Ishii et al. 2010; } \\
\text { Wan Ahmad et al. 2015) }\end{array}$ \\
\hline Protein carbonyls & $\begin{array}{l}\text { Lysine, proline and } \\
\text { threonine }\end{array}$ & $\begin{array}{l}\text { Chronic periodontitis, familial } \\
\text { hypercholesterolemia, acute } \\
\text { pancreatitis, Alzheimer's disease, } \\
\text { multiple sclerosis and myocardial } \\
\text { infarction }\end{array}$ & $\begin{array}{l}\text { (Baltacioğlu et al. 2008; Korolainen } \\
\text { et al. 2006; Miller et al. 2012; Paton } \\
\text { et al. 2010; Pirinccioglu et al. 2010; } \\
\text { Winterbourn et al. 2003) }\end{array}$ \\
\hline
\end{tabular}


been extensively used as an indicator of the occurrence of OS. The most commonly biomarkers of oxidative DNA damage are 8-oxo-7, 8-dihydroguanine (8-oxoGua) and 2,6-diamino-4-hydroxy-5-formamidopyrimidine. LPOderived DNA adducts have been suggested as potential biomarkers for oxidative stress to generate ethenopurinone, propano-purinone and pyrimido-purinone DNA base adducts (Blair 2008). Surprisingly, base excision repair of oxidative purine modifications is vulnerable to OS, while the nucleotide excision repair of pyrimidine dimers is not (Eiberger et al. 2008). Oxidized DNA damage induced by oxidative stress play a key role in human carcinogenesis (Kryston et al. 2011) and has often been linked to other pathological conditions such as Alzheimer's disease (Moreira et al. 2008), aging and neurodegenerative diseases (Radak et al.2011). Currently, several approaches are applied for investigation as indicator of oxidative stressinduced tissue damage such as microRNAs, cytokinesis block-micronucleus (CBMN-cytome) assay and telomere integrity assay (Prasad et al. 2015; Ren et al. 2015; Wang et al. 2010).

\section{OXIDATIVE STRESS-RELATED SYSTEMIC PATHOLOGY}

Overwhelm production of oxidants and or inefficiency and insufficiency of antioxidant defense system cause oS leading to the fundamental cellular and tissue damages and consequently affecting specialized organs or systems. This review focused on the nervous system, the cardiovascular system, the lung, the liver and the kidney.

\section{PATHOlOGy OF The NeRVous System}

OS has been implicated in the pathogenesis of both ischemic brain and neurodegenerative diseases including Alzheimer's disease (AD), Parkinson's disease (PD) and amyotrophic lateral sclerosis (ALS) (Uttara et al. 2009). Due to high oxidative phosphorylation and low level of endogenous antioxidants, the nervous system is more susceptible to oxidative damage than any other organs (Warner et al. 2004). As in ischemia, neuronal cells can be damaged through many mechanisms that are glutamate excitotoxicity, inflammation and OS. Both excitotoxicity and inflammation also cause os in common (Dong et al. 2009). Glutamate excitotoxicity activates NMDA receptor or even $\mathrm{Ca}^{2+}$-permeable AMPA receptor resulting in toxic increase of $\mathrm{Ca}^{2+}$ in cells (Nakka et al. 2008). $\mathrm{Ca}^{2+}$-dependent enzymes such as neuronal NOS (nNOS) and Phospholipase A2 (PLA2) produce peroxynitrite and superoxide anion damaging macromolecules and mitochondria (Godínez-Rubí et al. 2013; Sun et al. 2007). Mitochondrial dysfunction in brain even causes ROS/RNS production. Additionally, brains contain a high percentage of polyunsaturated fatty acids which are vulnerably susceptible to interaction with ROS/RNS leading to LPO (Sun et al. 2007). Inflammation which is the complex response to harmful stimuli particularly cell damage recruits white blood cells such as neutrophil releasing oxygen-free radicals and proteolytic enzymes (Wang et al. 2006). Matrix metalloproteinase destroys blood-brain barrier leading to vasogenic brain edema which worsens cerebral blood flow (Kahle et al.2009). Os causes the oxidation of macromolecules including lipid, protein, RNA, and DNA which consequence elicits various pathologies in nervous system. Not only severe reduction of cerebral blood flow in focal cerebral ischemia or ischemic reperfusion causes reactive oxygen species but also mild reduction of cerebral blood flow which is virtually no reperfusion like chronic cerebral hypoperfusion can also generate reactive oxygen species leading to neuronal death and impairments of learning and memory (Dong et al. 2011; Koomhin et al. 2012; Xu et al. 2009). Extracellular amyloid plaques, intracellular neurofibrillary tangles, amyloid- $\beta$ peptide $(\mathrm{A} \beta)$ accumulation and synapse loss can be found in $\mathrm{AD}$ brains. The excessive release of $\mathrm{A} \beta$ in $\mathrm{AD}$ patients causes OS via NMDA receptor-dependent mechanism (De Felice et al. 2007). A $\beta$ generates ROS in a metal-catalyzed reaction which damages neuronal membrane lipid, protein and DNA ultimately, triggers neurodegeneration (Pimentel et al. 2012). It induces OS-mediated neuronal apoptosis by eliciting a SAPK-dependent multiple regulation of proapoptotic mitochondrial pathways involving both p53, bcl-2 and pro-death BNIP3 genes (Tamagno et al. 2003; Zhang et al. 2007). Inflammatory response also occurred as the consequence of NOD-like receptor family pyrin domain containing 1 (NLRP1) inflammasome-induced caspase1 activation (Tan et al. 2014). In addition, os induced by A $\beta$ may result in the impairment of astrocytic glutamate uptake which also result in the increase of extracellular glutamate supporting glutamate excitotoxicity-induced os (Matos et al. 2012). PD is defined by death of dopaminergic neurons in the substantia nigra pars compacta and is associated with the deficiency of the neurotransmitter dopamine in the corpus striatum. Etiology of the disease is still obscured. $\alpha$-synuclein aggregation is the typical feature in extracellular space of substantia nigra (Pimentel et al. 2012). The aggregation may activate microglia respiratory burst resulting in ROS production and causing dopaminergic neuron degeneration (Zhang et al. 2005). Striatal os was increased in PD patients which is related with disease severity, particularly in the contralateral striatum (Ikawa et al. 2011). Postmortem brain tissues have suggested that ROS/RNS are involved in neurodegeneration of PD patients (Danielson \& Andersen 2008). Depletion of GSH levels and high levels of HNE and 8-hydroxyguanosine are common in brain tissues of PD patients (Danielson \& Andersen 2008). NMDA receptor-dependent mechanism may be involve in pathological mechanisms suggested by alleviation of symptoms in PD animal model after NMDA receptor antagonist applications (Dauer \& Przedborski 2003). ALS is characterized by progressive injury and death of lower motor neurons in the spinal cord and brainstem and upper motor neurons in the motor cortex which leads to muscle weakness, wasting and spasticity (Barber et al. 2006). Approximately $90 \%$ of all ALS cases are sporadic disease, while $10 \%$ of individuals ALS are familial disease 
(Menzies et al. 2002). Base on dying back hypothesis, the pathology firstly occurs at presynaptic terminals and Os takes a major contribution in pathogenesis (Pollari et al. 2014). OS contributes to motor neuron injury and death by either increased ROS/RNS production or reduced activity and levels of antioxidant defense system (Babu et al. 2008). Alterations of copper and iron metabolism undergo redox cycling and generate ROS and contribute to the induction of cell death pathways (Carri et al. 2003). Mitochondrial oxidative damage contributes to the pathogenesis of sporadic ALS (Murata et al. 2008). Additionally, mitochondrial dysfunction has been linked to the ALS variants of SOD1 (Shi et al. 2010). Mutations in the copper and zinc-superoxide dismutase (SOD1) gene implicate OS in the pathogenesis of familial ALS (Catherine 1995). Moreover, aberrant accumulation of A 342 in ALS spinal cord motor neurons is associated with os which may play a role in the pathogenesis of neurodegeneration in ALS (Calingasan et al. 2005). Increased LPO and protein glycoxidation in the spinal cord motor neurons and glial cells of sporadic ALS patients is implicated in motor neuron degeneration (Shibata et al. 2001). Oxidative stress biomarkers are demonstrated in high levels including LPO product, HNE, protein carbonyl in spinal cord and motor cortex and oxidized DNA adduct, 8-hydroxy-2'-deoxyguanosine in whole cervical spinal cord of sporadic ALS patients (Barber 2006). Glutamate transporter dysfunction was shown in animal study of ALS (Le Verche et al. 2011). In 2005, Rothstein found that upregulation of glutamate transporter especially by $\beta$-lactam antibiotics delayed neuronal death and muscle strength in animal model of the fatal disease ALS (Rothstein et al. 2005). It suggests that the contribution of glutamate excitotoxicity also take a crucial role in pathogenesis. The excitotoxicity observed in the model may be a cause of reactive oxygen species production in the disease. Taken together, the development of treatments focusing on OS in both direct and indirect ways through other mechanisms such as glutamate excitotoxicity and inflammation have a promising future on both cerebral ischemia and other neurodegenerative diseases.

\section{PATHOLOGY OF THE CARDiOVASCULAR SYSTEM}

Several cardiovascular diseases are resulted from complications of atherosclerosis. Atherosclerosis is a multifactorial disease which refers to the buildup of plaques (fats and cholesterol) in arterial walls. It can affect any artery in the body such as arteries in the heart, brain and kidneys which eventually restricts blood flow. Several risk factors including hypertension, hyperlipidemia, diabetes and cigarette smoking are involved in the development of atherosclerosis. Underlying mechanisms contributing to the disease process are not completely understood. Previous studies believed that os plays a crucial role in the pathogenesis of atherosclerotic disease. The generation of ROS and oxidation of low density lipoprotein (LDL) play the key roles in the oxidative signaling pathway to vascular inflammation from the initiation of fatty streak development to plaque rupture (Cipollone et al. 2007). Oxidative DNA damage biomarker, 8-Hydroxy-2'-deoxyguanosine (8$\mathrm{OHdG}$ ) were found to be at high level in aorta fragments taken from patients suffering from severe atherosclerotic lesions (De Flora et al. 1997). In type 2 diabetic patients, the accumulation of OS-associated gene polymorphisms of several enzymes including myeloperoxidase, human paraoxonase and $\mathrm{NAD}(\mathrm{P}) \mathrm{H}$ oxidase is likely associated with the progression of carotid atherosclerosis (Katakami et al.2009). Lipid peroxidation marker, 8-iso-prostaglandin F2 is possible linked with alterations of arterial elastic properties which are the sign of early vascular damage in atherosclerosis (Kals et al. 2006).

\section{PATHOLOGY OF THE LUNG}

OS is one of the most important causes of various lung diseases including chronic obstructive pulmonary disease (COPD), bronchopulmonary dysplasia, pulmonary sarcoidosis, asthma, idiopathic pulmonary fibrosis (IPF) and lung cancer. COPD is one of the leading causes of morbidity and mortality worldwide which is primarily associated with cigarette smoking. Excessive os contributes to pathophysiology of COPD. OS-triggered apoptosis of alveolar structural cells, including epithelial cells and thus may be an underlying mechanism in the development of COPD (MacNee 2001). High oxygen level, lower antioxidant defense, infection and inflammation susceptibility and excess free iron are the risk factors contributing to os. A lower antioxidant is more susceptible to os because of uncontrolled formation of free radicals. Exposure to infection and inflammation activated phagocytic cells and eventually release large amounts of ROS. Iron is the transitional metal which is found abundant in human body. It is the important metal to produce toxic hydroxyl radical by participating in the Fenton reaction $\left(\mathrm{H}_{2} \mathrm{O}_{2}+\mathrm{Fe}^{2+}\right.$ $\left.\rightarrow \mathrm{OH}^{-}+\mathrm{OH}^{-}+\mathrm{Fe}^{3+}\right)$. In preterm infants, these factors contributed to OS which triggers permanently molecular and cellular changes of lung leading to chronic lung disease or bronchopulmonary dysplasia (Pitkänen \& Hallman 1998; Saugstad 2003). Idiopathic pulmonary fibrosis is a fatal fibrotic disorder characterized by an abnormal accumulation of fibroblast/myofibroblast resulting in severe dyspnea and impairment of pulmonary function. Serum levels of OS are increased in IPF patients suggested that OS plays a possible role in the pathogenesis of IPF (Daniil et al. 2008). A potent stimulator of myofibroblast differentiation and proliferation, TGF- $\beta 1$ is believed to play a substantial role for OS in IPF. Treatment with enzymatic antioxidant such as extracellular superoxide dismutase can inhibit activated TGF- $\beta 1$ and the development of persistent pulmonary fibrosis in animal model (Cui et al. 2011).

\section{PATHOLOGY OF THE LIVER}

The important cause of alcoholic liver disease is os by which ethanol induces increased mitochondrial ROS 
production in the liver. Patients with alcoholic liver disease exhibit the high levels of serum oxidative stress biomarker, MDA associated with the increase in severity of the disease and demonstrated low levels of serum vitamins $E$ and C (Masalkar \& Abhang 2005). The exact mechanism is unknown. Bailey and Cunningham (2002) believed that increased oxidant levels are linked with mitochondrial metabolism through oxidative process and/or alteration of mitochondrial electron transport chain. Moreover, ROS might have the effect on inactivation of mitochondrial proteins which would diminish mitochondrial function and ultimately cause some deleterious effects to hepatocytes in alcohol abusers (Bailey \& Cunningham 2002). The generation of ROS and RNS is stimulated by cytokineinduced oxidative stress signals in hepatic parenchymal cells and via the induction of Kupffer cells and inflammatory cells. The shift in the balance of cytokines in hepatocytes including tumor necrotic factor (TNF)- $\alpha$, interleukin (IL)- $1 \beta$ and IL- 6 also contributes to hepatic damage in alcoholic hepatitis (Hoek \& Pastorino 2002). Fatty liver disease associated with chronic alcohol consumption or obesity/ type 2 diabetes is linked to mitochondrial defect. The alterations of mitochondrial genome and proteome cause loss of mitochondrial respiration, the inability to maintain sufficient ATP concentrations and a further increased ROS and RNS generation ultimately resulting in OS (Mantena et al. 2008). Non-alcoholic liver disease includes a spectrum of hepatic steatosis, steatohepatitis and fibrosis which is also linked with OS. Previous study demonstrated that the transgenic Ren 2 rats, harboring the mouse rennin gene with elevated tissue Angiotensin II, developed significant hepatic steatosis by 9 weeks of age and developed to marked steatohepatitis and fibrosis by 12 weeks which are associated with the increased levels of hepatic ROS and LPO. After treatment with an angiotensin type 1 receptor blocker or superoxide dismutase/catalase mimetic, hepatic indices of steatosis, fibrosis and OS are attenuated (Wei et al. 2008). Moreover, the development of hyperdynamic circulation in portal hypertension is also associated with os by impact on function of vascular smooth muscle. Normally, ROS and RNS are recognized as the regulatory molecules in signaling pathways of normal vascular smooth muscle cells depending on concentration, cellular compartment of generation and access, nature of action and target site of molecular species. However, their action depends on cellular antioxidant status (Bomzon \& Ljubuncic 2001). The toxicity of chemotherapeutic agent such as cisplatin also caused the liver damage which os was implicated in the pathogenesis (Palipoch \& Punsawad 2013; Palipoch et al. 2014). Heavy metals such as lead nitrate can induce OS in liver by increased LPO, decreased concentrations of hepatic glutathione and decreased activities of enzymatic antioxidants including catalase, glutathione reductase and glutathione peroxidase in fish. Medicinal plant-derived antioxidants are able to reduce hepatic pathology induced by OS in $\mathrm{Pb}\left(\mathrm{NO}_{3}\right)_{2}$-exposed fish (Palipoch et al. 2011a, 2011b).

\section{PATHOLOGY OF THE KIDNEY}

In fish model, os can cause various kidneys alterations via increased oxidant production and decreased antioxidant defense system (Palipoch et al. 2011a, 2011b). According to Robbins et al. (2002), generation of ROS induced by irradiation leads to nephropathy in rats via os induction. Detection of specific DNA oxidative stress marker, $8-\mathrm{OHdG}$ and localized kidney irradiation illustrates a marked, dose-independent increase in glomerular and tubular cell nuclear DNA oxidation which is associated with persistent and chronic oxidative stress. Moreover, a relation between chronic oxidative stress and tubulointerstitial fibrosis in irradiated kidney remains to be established. Antioxidant such as superoxide dismutase is demonstrated as an effective approach in the treatment of kidney fibrosis induced by irradiation (Robbins et al. 2002). Aykanat et al. (2011) believed that chronic kidney disease especially in the uremic state and dialysis treatment is believed to cause the imbalanced antioxidant defense system and the increased ROS production consequently leading to OS. Pediatric patients with chronic kidney disease including pre-dialysis, regular hemodialysis and received kidney transplantation exhibit increased oxidative DNA damage using comet assay (Aykanat et al. 2011). Pawlak et al. (2007) indicated that uremic patients illustrated with impaired renal function and duration of dialysis treatment are associated with increased of OS. Compared to healthy control, the increased $\mathrm{Cu} / \mathrm{Zn}$ superoxide dismutase is found in peritoneal dialysis and maintenance hemodialysis patients. Antioxidant therapy might be a new method to reduce intradialytic os (Pawlak et al. 2007).

\section{CONCLUSION}

OS has been implicated in various pathologies via underlying mechanism of increased ROS/RNS production and/or decreased scavenging ability of antioxidant defense system. Oxidants play the key role to oxidize several macromolecules especially lipid, protein and DNA and ultimately lead to injury of various organs or systems. Detections of biomarkers including lipid, protein and DNA oxidation products from blood and urine are the important methods to measure oxidative stress status. Future investigation will provided the effective approach to prevent and or treat OS-associated diseases. Currently, exogenous antioxidant supplementations from various sources especially medicinal plants are believed to ameliorate pathologies induced by OS.

\section{ACKNOWLEDGMENTS}

This work was partially supported by the Institute of Research and Development, Walailak University, Thailand. The authors sincerely thank the Dean and all staff at the School of Medicine, Walailak University for their kind support. 


\section{REFERENCES}

Arnouk, H., Lee, H., Zhang, R., Chung, H., Hunt, R.C. \& Jahng, W.J. 2011.Early biosignature of oxidative stress in the retinal pigment epithelium. Journal of Proteomics 74(2): 254-261.

Ayala,A., Muñoz, M.F. \& Argüelles, S. 2014 . Lipid peroxidation: Production, metabolism, and signaling mechanisms of malondialdehyde and 4-hydroxy-2-nonenal. Oxidative Medicine and Cellular Longevity 2014: 360438.

Aykanat, B., Demircigil, G.C., Fidan, K., Buyan, N., Gulleroglu, K., Baskin, E., Bayrakci, U.S., Sepici, A., Buyukkaragoz, B., Karakayali, H., Haberal, M. \& Burgaz, S. 2011. Basal damage and oxidative DNA damage in children with chronic kidney disease measured by use of the comet assay. Mutation Research 725(1-2): 22-28.

Babu, G.N., Kumar, A., Chandra, R., Puri, S.K., Singh, R.L., Kalita, J. \& Misra, U.K. 2008. Oxidant-antioxidant imbalance in the erythrocytes of sporadic amyotrophic lateral sclerosis patients correlates with the progression of disease. Neurochemistry International 52(6): 1284-1289.

Bailey, S.M. \& Cunningham, C.C. 2002. Contribution of mitochondria to oxidative stress associated with alcoholic liver disease. Free Radical Biology and Medicine 32(1): 11-16.

Baltacıŏglu, E., Akalın,F.A.,Alver,A., Değer, O. \& Karabulut, E. 2008. Protein carbonyl levels in serum and gingival crevicular fluid in patients with chronic periodontitis. Archives of Oral Biology 53(8): 716-722.

Barber, S.C., Mead, R.J. \& Shaw, P.J. 2006. Oxidative stress in ALS: A mechanism of neurodegeneration and a therapeutic target. Biochimica et Biophysica Acta-Molecular Basis of Disease 1762(11-12): 1051-1067.

Bargagli, E., Olivieri, C., Bennett, D., Prasse, A., MullerQuernheim, J. \& Rottoli, P. 2009. Oxidative stress in the pathogenesis of diffuse lung diseases: A review. Respiratory Medicine 103(9): 1245-1256.

Bhimaraj, A. \& Tang, W.H.W. 2012. Role of oxidative stress in disease progression in stage B, a pre-cursor of heart failure. Heart Failure Clinics 8(1): 101-111.

Blair, I.A. 2008. DNA adducts with lipid peroxidation products. Journal of Biological Chemistry 283(23): 15545-15549.

Blumberg, J. 2004. Use of biomarkers of oxidative stress in research studies. Journal of Nutrition 134(11): 3188S-3189S.

Bomzon, A. \& Ljubuncic, P. 2001. Oxidative stress and vascular smooth muscle cell function in liver disease. Pharmacology and Therapeutics 89(3): 295-308.

Brzóska, M.M., Rogalska, J. \& Kupraszewicz, E. 2011. The involvement of oxidative stress in the mechanisms of damaging cadmium action in bone tissue: A study in a rat model of moderate and relatively high human exposure. Toxicology and Applied Pharmacology 250(3): 327-335.

Calingasan, N.Y., Chen, J., Kiaei, M. \& Beal, M.F. 2005. $\beta$-amyloid 42 accumulation in the lumbar spinal cord motor neurons of amyotrophic lateral sclerosis patients. Neurobiology of Disease 19(1-2): 340-347.

Carrı ', M.T., Ferri, A., Cozzolino, M., Calabrese, L. \& Rotilio, G. 2003. Neurodegeneration in amyotrophic lateral sclerosis: The role of oxidative stress and altered homeostasis of metals. Brain Research Bulletin 61(4): 365-374

Catherine, B. 1995. Oxidative stress: Its role in the pathogenesis of amyotrophic lateral sclerosis. Journal of the Neurological Sciences 129(supplement): 81-84.

Cherubini,A., Ruggiero, C., Polidori, M.C. \& Mecocci, P. 2005.
Potential markers of oxidative stress in stroke. Free Radical Biology and Medicine 39(7): 841-852.

Choi, D.H., Lee, K.H., Kim, J.H., Seo, J.H., Kim, H.Y., Shin, C.Y.,Han, J.S., Han, S.H., Kim, Y.S. \& Lee, J. 2014. NADPH oxidase 1, a novel molecular source of ROS in hippocampal neuronal death in vascular dementia. Antioxidants and Redox Signaling 21(4): 533-550.

Cipollone, F., Fazia, M.L.\& Mezzetti,A. 2007. Oxidative stress, inflammation and atherosclerotic plaque development International Congress Series 1303: 35-40.

Cracowski, J.L., Durand, T. \& Bessard, G. 2002. Isoprostanes as a biomarker of lipid peroxidation in humans: Physiology, pharmacology and clinical implications. Trends in Pharmacological Sciences 23(8): 360-366.

Cui, Y., Robertson, J., Maharaj, S., Waldhauser, L., Niu, J., Wang, J., Farkas, L., Kolb, M. \& Gauldie, J. 2011 . Oxidative stress contributes to the induction and persistence of TGF- $\beta 1$ induced pulmonary fibrosis. The International Journal of Biochemistry and Cell Biology 43(8): 1122-1133.

Dalle-Donne, I., Rossi, R., Giustarini, D., Milzani,A. \& Colombo, R. 2003. Protein carbonyl groups as biomarkers of oxidative stress. Clinica Chimica Acta 329(1-2): 23-38.

Danielson, S.R. \& Andersen, J.K. 2008. Oxidative and nitrative protein modifications in Parkinson's disease. Free Radical Biology and Medicine 44(10): 1787-1794.

Daniil, Z.D., Papageorgiou, E., Koutsokera, A., Kostikas, K., Kiropoulos, T., Papaioannou, A.I. \& Gourgoulianis, K.I. 2008. Serum levels of oxidative stress as a marker of disease severity in idiopathic pulmonary fibrosis. Pulmonary Pharmacology and Therapeutics 21(1): 26-31.

Das, S.K. \& Vasudevan, D.M. 2007. Alcohol-induced oxidative stress. Life Sciences 81(3): 177-187.

Dauer, W. \& Przedborski, S. 2003. Parkinson's disease: Mechanisms and models. Neuron 39(6): 889-909.

De Felice, F.G., Velasco, P.T., Lambert, M.P., Viola, K., Fernandez, S.J., Ferreira, S.T. \& Klein, W.L. 2007. Abeta oligomers induce neuronal oxidative stress through an $\mathrm{N}$-methyl-D-aspartate receptor-dependent mechanism that is blocked by the Alzheime drug memantine. The Journal of Biological Chemistry 282(15): 11590-11601.

De Flora, S., Izzotti, A., Walsh, D., Degan, P., Petrilli, G.L. \& Lewtas, J. 1997. Molecular epidemiology of atherosclerosis. FASEB Journal 11(12): 1021-1031.

Dong, H., Shi, Q., Song, X., Fu, J., Hu, L., Xu, D., Su, C., Xia, X., Song, E. \& Song, Y. 2015. Polychlorinated biphenyl quinone induces oxidative DNA damage and repair responses: The activations of NHEJ, BER and NER via ATM-p53 signaling axis. Toxicology and Applied Pharmacology 286(1): 10-16.

Dong, X.X., Wang, Y. \& Qin, Z.H. 2009. Molecular mechanisms of excitotoxicity and their relevance to pathogenesis of neurodegenerative diseases. Acta Pharmacologica Sinica 30(4): 379-387.

Dong, Y.F., Kataoka, K., Toyama, K., Sueta, D., Koibuchi, N., Yamamoto, E., Yata, K., Tomimoto, H., Ogawa, H. \& Kim-Mitsuyama, S. 2011. Attenuation of brain damage and cognitive impairment by direct renin inhibition in mice with chronic cerebral hypoperfusion. Hypertension 58(4): 635-642.

Dosek, A., Ohno, H., Acs, Z., Taylor, A.W. \& Radak, Z. 2007. High altitude and oxidative stress. Respiratory Physiology and Neurobiology 158(2-3): 128-131.

Duryee, M.J., Klassen, L.W., Schaffert, C.S., Tuma, D.J., Hunter, 
C.D., Garvin, R.P., Anderson, D.R. \& Thiele, G.M. 2010. Malondialdehyde-acetaldehyde adduct is the dominant epitope after MDA modification of proteins in atherosclerosis. Free Radical Biology and Medicine 49(10): 1480-1486.

Dzięgielewska-Gęsiak, S., Wysocka, E., Michalak, S., Nowakowska-Zajdel, E., Kokot, T. \& Muc-Wierzgoń, M. 2014. Role of lipid peroxidation products, plasma total antioxidant status, and $\mathrm{Cu}$-, $\mathrm{Zn}$-superoxide dismutase activity as biomarkers of oxidative stress in elderly prediabetics. Oxidative Medicine and Cellular Longevity 2014:987303.

Eiberger, W., Volkmer, B., Amouroux, R., Dhérin, C., Radicella, J.P. \& Epe, B. 2008. Oxidative stress impairs the repair of oxidative DNA base modifications in human skin fibroblasts and melanoma cells. DNA Repair 7(6): 912-921.

Elshal, M.F., El-Sayed, I.H., Elsaied, M.A., El-Masry, S.A. \& Kumosani, T.A. 2009. Sperm head defects and disturbances in spermatozoal chromatin and DNA integrities in idiopathic infertile subjects: Association with cigarette smoking. Clinical Biochemistry 42(7-8): 589-594.

Esterbauer, H., Schaur, R.J. \& Zollner, H. 1991. Chemistry and biochemistry of 4-hydroxynonenal, malonaldehyde and related aldehydes. Free Radical Biology and Medicine 11(1): 81-128.

Etsuo, N. 2009. Lipid peroxidation: Physiological levels and dual biological effects. Free Radical Biology and Medicine 47(5): 469-484.

Feillet-Coudray, C., Sutra, T., Fouret, G., Ramos, J., WrutniakCabello, C., Cabello, G., Cristol, J.P. \& Coudray, C. 2009. Oxidative stress in rats fed a high-fat high-sucrose diet and preventive effect of polyphenols: Involvement of mitochondrial and $\mathrm{NAD}(\mathrm{P}) \mathrm{H}$ oxidase systems. Free Radical Biology and Medicine 46(5): 624-632.

Gao, L.P., Cheng, M.L., Chou, H.J., Yang, Y.H., Ho, H.Y. \& Chiu, D.T.Y. 2009. Ineffective GSH regeneration enhances G6PDknockdown Hep G2 cell sensitivity to diamide-induced oxidative damage. Free Radical Biology and Medicine 47(5): 529-535.

Godínez-Rubí, M., Rojas-Mayorquín, A.E. \& Ortuño-Sahagún, D. 2013. Nitric oxide donors as neuroprotective agents after an ischemic stroke-related inflammatory reaction. Oxidive Medicine and Cellular Longevity 2013: 297357.

Guerra, L.N., Ríos de Molina, M.D.C., Miler, E.A., Moiguer, S., Karner, M. \& Burdman, J.A. 2005. Antioxidants and methimazole in the treatment of Graves' disease: Effect on urinary malondialdehyde levels. Clinica Chimica Acta 352(1-2): 115-120.

Gurer-Orhan, H., Sabır, H.U. \& Özgüneş, H. 2004. Correlation between clinical indicators of lead poisoning and oxidative stress parameters in controls and lead-exposed workers. Toxicology 195(2-3): 147-154.

Hoek, J.B. \& Pastorino, J.G. 2002. Ethanol, oxidative stress, and cytokine-induced liver cell injury. Alcohol 27(1): 63-68.

Horton, A.A. \& Fairhurst, S. 1987. Lipid peroxidation and mechanisms of toxicity. Critical Reviews in Toxicology 18(1): 27-79.

Ikawa, M., Okazawa, H., Kudo, T., Kuriyama, M., Fujibayashi, Y. \& Yoneda, M. 2011. Evaluation of striatal oxidative stress in patients with Parkinson's disease using [62Cu]ATSM PET. Nuclear Medicine and Biology 38(7): 945-951.

Ishii, Y., Sakamoto, T., Ito, R. \& Yanaga, K. 2010. F2-Isoprostanes and 2-arachidonylglycerol as biomarkers of lipid peroxidation in pigs with hepatic ischemia/reperfusion injury. Journal of Surgical Research 161(1): 139-145.
Kaarniranta, K., Ryhänen, T., Karjalainen, H.M., Lammi, M.J., Suuronen, T., Huhtala, A., Kontkanen, M., Teräsvirta, M., Uusitalo, H. \& Salminen, A. 2005. Geldanamycin increases 4-hydroxynonenal (HNE)-induced cell death in human retinal pigment epithelial cells. Neuroscience Letters 382(1-2): 185190.

Kadiiska, M.B., Gladen, B.C., Baird, D.D., Germolec,D., Graham, L.B., Parker, C.E., Nyska, A., Wachsman, J.T., Ames, B.N., Basu, S., Brot, N., Fitzgerald, G.A., Floyd, R.A., George, M., Heinecke, J.W., Hatch, G.E., Hensley, K., Lawson, J.A., Marnett, L.J., Morrow, J.D., Murray, D.M., Plastaras, J., Roberts, L.J., Rokach, J. 2nd., Shigenaga, M.K., Sohal, R.S., Sun, J., Tice, R.R., Van Thiel, D.H., Wellner, D., Walter, P.B., Tomer, K.B.,Mason, R.P. \& Barrett, J.C. 2005. Biomarkers of oxidative stress study II: Are oxidation products of lipids, proteins, and DNA markers of CCl4 poisoning? Free Radical Biology and Medicine 38(6): 698-710.

Kadiiska, M.B., Hatch, G.E., Nyska, A., Jones, D.P., Hensley, K., Stocker, R., George, M.M., van Thiel, D.H., Stadler, K., Barrett, J.C. \& Mason, R.P. 2011. Biomarkers of oxidative stress study IV: Ozone exposure of rats and its effect on antioxidants in plasma and bronchoalveolar lavage fluid. Free Radical Biology and Medicine 51(9): 1636-1642.

Kahle, K.T., Simard, J.M., Staley, K.J., Nahed, B.V., Jones, P.S. $\&$ Sun, D. 2009. Molecular mechanisms of ischemic cerebral edema: Role of electroneutral ion transport. Physiology (Bethesda) 24: 257-265.

Kals, J., Kampus, P., Kals, M., Zilmer, K., Kullisaar, T., Teesalu, R., Pulges, A. \& Zilmer, M. 2006. Impact of oxidative stress on arterial elasticity in patients with atherosclerosis. American Journal of Hypertension 19(9): 902-908.

Katakami, N., Sakamoto, K., Kaneto, H., Matsuhisa, M., Shimizu, I., Ishibashi, F., Osonoi, T., Kashiwagi,A., Kawamori, R.,Hori, M. \& Yamasaki, Y. 2009. Combined effect of oxidative stressrelated gene polymorphisms on atherosclerosis. Biochemical and Biophysical Research Communications 379(4): 861-865.

Kim, J.W., Yang, H., Cho, N., Kim, B., Kim, Y.C. \& Sung, S.H. 2015. Hepatoprotective constituents of Firmiana simplex stem bark against ethanol insult to primary rat hepatocytes. Pharmacognosy Magazine 11(41): 55-60.

Kim, M., Han, C.H. \& Lee, M.Y. 2014. NADPH oxidase and the cardiovascular toxicity associated with smoking. Toxicological Research 30(3): 149-157.

Kirisattayakul, W., Jintanaporn, W., Terdthai, T., Supaporn, M., Panakaporn, W. \& Jinatta, J. 2013. Cerebroprotective effect of Moringaoleifera against focal ischemic stroke induced by middle cerebral artery occlusion. Oxidative Medicine and Cellular Longevity 2013: 951415.

Koomhin,P., Tilokskulchai, K. \& Tapechum, S. 2012.Ceftriaxone improves spatial learning and memory in chronic cerebral hypoperfused rats. ScienceAsia 38: 356-363.

Korolainen, M.A., Goldsteins, G., Nyman, T.A., Alafuzoff, I., Koistinaho, J. \& Pirttilä, T. 2006. Oxidative modification of proteins in the frontal cortex of Alzheimer's disease brain. Neurobiology of Aging 27(1): 42-53.

Kryston, T.B., Georgiev, A.B., Pissis, P. \& Georgakilas, A.G. 2011. Role of oxidative stress and DNA damage in human carcinogenesis. Mutation Research 711(1-2): 193-201.

Kuo, H.W., Chou, S.Y., Hu, T.W., Wu, F.Y. \& Chen, D.J. 2007. Urinary 8-hydroxy-2'-deoxyguanosine (8-OHdG) and genetic polymorphisms in breast cancer patients. Mutation Research 631(1): 62-68. 
Kurutas, E.B., Gumusalan, Y., Cetinkaya, A. \& Dogan, E. 2015. Evaluation of method performance for oxidative stressbiomarkers in urine and biological variations in urine of patients with type 2 diabetes mellitus and diabetic nephropathy. Biological Procedures Online 17(1): 3.

Lee, J.S., Park, S.J., Cho, Y.S., Huh, J.W., Oh, Y.M. \& Lee, S.D. 2015. Role of AMP-activated protein kinase (AMPK) in smoking-induced lung inflammation and emphysema. Tuberculosis and Respiratory Diseases 78(1): 8-17.

Le Verche, V., Ikiz, B., Jacquier, A., Przedborski, S. \& Re, D.B. 2011. Glutamate pathway implication in amyotrophic lateral sclerosis: What is the signal in the noise? Journal of Receptor, Ligand and Channel Research 4: 1-22.

Luchese, C., Pinton, S. \& Nogueira, C.W. 2009. Brain and lungs of rats are differently affected by cigarette smoke exposure: Antioxidant effect of an organoselenium compound. Pharmacological Research 59(3): 194-201.

Lundby, C., Pilegaard, H., van Hall, G., Sander, M., Calbet, J., Loft, S. \& Møller, P. 2003. Oxidative DNA damage and repair in skeletal muscle of humans exposed to high-altitude hypoxia. Toxicology 192(2-3): 229-236.

MacNee, W. 2001. Oxidative stress and lung inflammation in airways disease. European Journal of Pharmacology 429(13): 195-207.

Mantena, S.K., King, A.L., Andringa, K.K., Eccleston, H.B. \& Bailey, S.M. 2008. Mitochondrial dysfunction and oxidative stress in the pathogenesis of alcohol- and obesity-induced fatty liver diseases. Free Radical Biology and Medicine 44(7): 1259-1272

Masalkar, P.D. \& Abhang, S.A. 2005. Oxidative stress and antioxidant status in patients with alcoholic liver disease. Clinica Chimica Acta 355(1-2): 61-65.

Mathy-Hartert, M., Hogge, L., Sanchez, C., Deby-Dupont, G., Crielaard, J.M. \& Henrotin, Y. 2008. Interleukin-1 $\beta$ and interleukin-6 disturb the antioxidant enzyme system in bovine chondrocytes: A possible explanation for oxidative stress generation. Osteoarthritis and Cartilage 16(7): 756-763.

Matos, M., Augusto, E., Machado, N.J., dos Santos-Rodrigues,A., Cunha, R.A. \& Agostinho, P. 2012. Astrocytic adenosine A2A receptors control the amyloid- $\beta$ peptide-induced decrease of glutamate uptake. Journal of Alzheimer's Disease 31(3): 555-567.

Matsubara, K., Higaki, T., Matsubara, Y.\& Nawa,A. 2015. Nitric oxide and reactive oxygen species in the pathogenesis of preeclampsia. International Journal of Molecular Sciences 16(3): 4600-4614

Mehlhase, J. \& Grune, T. 2002. Proteolytic response to oxidative stress in mammalian cells. Biological Chemistry 383(3-4): 559-567.

Menzies, F.M., Grierson, A.J., Cookson, M.R., Heath, P.R., Tomkins, J., Figlewicz, D.A., Ince, P.G. \& Shaw, P.J. Selective loss of neurofilament expression in $\mathrm{Cu} / \mathrm{Zn}$ superoxide dismutase (SOD1) linked amyotropic lateral sclerosis. Journal of Neurochemistry 82(5): 1118-1128.

Miller, E., Walczak, A., Saluk, J., Ponczek, M.B. \& Majsterek, I. 2012. Oxidative modification of patient's plasma proteins and its role in pathogenesis of multiple sclerosis. Clinical Biochemistry 45(1-2): 26-30.

Ming, X., Stein, T.P., Brimacombe, M., Johnson, W.G., Lambert, G.H. \& Wagner, G.C. 2005. Increased excretion of a lipid peroxidation biomarker in autism. Prostaglandins, Leukotrienes and Essential Fatty Acids 73(5): 379-384.
Moreira, P.I., Nunomura, A., Nakamura, M., Takeda, A., Shenk, J.C., Aliev, G., Smith, M.A. \& Perry, G. 2008. Nucleic acid oxidation in Alzheimer disease. Free Radical Biology and Medicine 44(8): 1493-1505.

Murata, T., Ohtsuka, C. \& Terayama, Y. 2008. Increased mitochondrial oxidative damage in patients with sporadic amyotrophic lateral sclerosis. Journal of the Neurological Sciences 267(1-2): 66-69.

Nakka, V.P., Gusain, A., Mehta, S.L. \& Raghubir, R. 2008. Molecularmechanisms of apoptosis in cerebral ischemia: Multiple neuroprotective opportunities. Molecular Neurobiology 37(1): 7-38.

Nomura, J., Busso, N., Ives, A., Matsui, C., Tsujimoto, S., Shirakura,T., Tamura, M., Kobayashi, T., So,A.\& Yamanaka, Y.2014. Xanthine oxidase inhibition by febuxostat attenuates experimental atherosclerosis in mice. Scientific Reports 4 45-54.

Nourazarian, A.R., Kangari, P. \& Salmaninejad, A. 2014. Roles of oxidative stress in the development and progression of breast cancer. Asian Pacific Journal of Cancer Prevention 15(12): 4745-4751

Palipoch, S. 2013. A review of oxidative stress in acute kidney injury: Protective role of medicinal plants-derived antioxidants. African Journal of Traditional, Complementary and Alternative Medicines 10(4): 88-93.

Palipoch, S. \& Punsawad, C. 2013. Biochemical and histological study of rat liver and kidney injury induced by Cisplatin Journal of Toxicologic Pathology 26(3): 293-299.

Palipoch, S., Punsawad, C., Koomhin, P. \& Suwannalert, P. 2014. Hepatoprotective effect of curcumin and alphatocopherol against cisplatin-induced oxidative stress. $B M C$ Complementary and Alternative Medicine 14: 111.

Palipoch, S., Jiraungkoorskul,W., Tansatit, T., Preyavichyapugdee, N., Jaikua, W. \& Kosai, P. 2011a. Effect of Thunbergia laurifolia (Linn) leaf extract dietary supplement against lead toxicity in Nile Tilapia (Oreochromis niloticus). World Journal of Fish and Marine Sciences 3(1): 1-9.

Palipoch, S., Jiraungkoorskul,W., Tansatit, T., Preyavichyapugdee, N., Jaikua, W. \& Kosai, P. 2011b. Protective efficiency of Thunbergia laurifolia leaf extract against lead (II) nitrateinduced toxicity in Oreochromis niloticus. Journal of Medicinal Plants Research 5(5): 719-728.

Parker, C.E., Graham, L.B., Nguyen, M.N., Gladen, B.C., Kadiiska, M.B., Barrett, J.C. \& Tomer, K.B. 2001. An improved GC/MS-based procedure for the quantitation of the isoprostane 15-F2t-IsoP in rat plasma. Molecular Biotechnology 18(2): 105-118.

Paton, L.N., Mocatta, T.J., Richards, A.M. \& Winterbourn, C.C. 2010. Increased thrombin-induced polymerization of fibrinogen associated with high protein carbonyl levels in plasma from patients post myocardial infarction. Free Radical Biology and Medicine 48(2): 223-229.

Pawlak, K., Pawlak, D. \& Mysliwiec, M. 2007. Impaired renal function and duration of dialysis therapy are associated with oxidative stress and proatherogenic cytokine levels in patients with end-stage renal disease. Clinical Biochemistry 40(1-2): 81-85.

Pimentel, C., Batista-Nascimento, L., Rodrigues-Pousada, C. \& Menezes, R.A. 2012. Oxidative stress in Alzheimer's and Parkinson's diseases: Insights from the yeast Saccharomyces cerevisiae. Oxidive Medicine and Cellular Longevity 2012: 132146.

Pirinccioglu, A.G., Gökalp, D., Pirinccioglu, M., Kizil, G 
\& Kizil, M. 2010. Malondialdehyde (MDA) and protein carbonyl (PCO) levels as biomarkers of oxidative stress in subjects with familial hypercholesterolemia. Clinical Biochemistry 43(15): 1220-1224.

Pitkänen, O.M. \& Hallman, M. 1998. Evidence for increased oxidative stress in preterm infants eventually developing chronic lung disease. Seminars in Neonatology 3(3): 199-205.

Poli, G., Biasi, F. \& Leonarduzzi, G. 2008. 4-Hydroxynonenalprotein adducts: A reliable biomarker of lipid oxidation in liver diseases. Molecular Aspects of Medicine 29(1-2): 67-71.

Pollari, E., Goldsteins, G., Bart, G., Koistinaho, J . \& Giniatullin, R. 2014. The role of oxidative stress in degeneration of the neuromuscular junction in amyotrophic lateral sclerosis. Frontiers in Cellular Neuroscience 8: 131.

Prasad, M., Bronson, S.C., Warrier, T., Badarinath, A., Rai, S., Baid, K., Sitaraman, S., George, A., Moses, A., Saraswathy, R., Vasuki, R. \& Shanmugam, A. 2015. Evaluation of DNA damage in Type 2 diabetes mellitus patients with and without peripheral neuropathy: A study in South Indian population. Journal of Natural Science, Biology and Medicine 6(1): 80-84.

Protano, C., Andreoli, R., Mutti, A., Petti, S. \& Vitali, M. 2014. Biomarkers of oxidative stress to nucleic acids: Background levels and effects of body mass index and life-style factors in an urban paediatric population. The Science of Total Environment 500-501: 44-51.

Rác, M., Křupka, M., Binder, S., Sedlářová, M., Matušková, Z., Raška, M. \& Pospíšil, P. 2015. Oxidative damage of U937 human leukemic cells caused by hydroxyl radical results in singlet oxygen formation. PLOS ONE 10(3): e0116958.

Radak, Z., Zhao, Z., Goto, S. \& Koltai, E. 2011. Age-associated neurodegeneration and oxidative damage to lipids, proteins and DNA. Molecular Aspects of Medicine 32(4-6): 305-315.

Rall, L.C., Roubenoff, R., Meydani, S.N., Han, S.N. \& Meydani, M. 2000. Urinary 8-hydroxy-2'-deoxyguanosine (8-OHdG) as a marker of oxidative stress in rheumatoid arthritis and aging: Effect of progressive resistance training. The Journal of Nutritional Biochemistry 11(11): 581-584.

Ren, X., Gaile, D.P., Gong, Z., Qiu, W., Ge, Y., Zhang, C., Huang, C., Yan, H., Olson, J.R., Kavanagh, T.J. \& Wu, H. 2015. Arsenic responsive microRNAs in vivo and their potential involvement in arsenic-induced oxidative stress. Toxicology and Applied Pharmacology 283(3): 198-209.

Robbins, M.E.C., Zhao, W., Davis, C.S., Toyokuni, S. \& Bonsib, S.M. 2002. Radiation-induced kidney injury: A role for chronic oxidative stress? Micron 33(2): 133-141.

Rothstein, J.D., Patel, S., Regan, M.R., Haenggeli, C., Huang, Y.H., Bergles, D.E., Jin, L., Dykes Hoberg, M., Vidensky, S., Chung, D.S., Toan, S.V., Bruijn, L.I., Su, Z.Z., Gupta, P. \& Fisher, P.B. 2005. Beta-lactam antibiotics offer neuroprotection by increasing glutamate transporter expression. Nature 433(7021): 73-77.

Saleh, R.A.,Agarwal,A., Sharma, R.K., Nelson, D.R.\& Thomas, A.J. Jr. 2002. Effect of cigarette smoking on levels of seminal oxidative stress in infertile men: A prospective study. Fertility and Sterility 78(3): 491-499.

Saugstad, O.D. 2003. Bronchopulmonary dysplasia-oxidative stress and antioxidants. Seminars in Neonatology 8(1): 39-49.

Shi, P., Gal, J., Kwinter, D.M., Liu, X. \& Zhu, H. 2010. Mitochondrial dysfunction in amyotrophic lateral sclerosis. Biochimica et Biophysica Acta 1802(1): 45-51.

Shibata, N., Nagai, R., Uchida, K., Horiuchi, S., Yamada, S.,
Hirano, A., Kawaguchi, M., Yamamoto, T., Sasaki, S. \& Kobayashi, M. 2001. Morphological evidence for lipid peroxidation and protein glycoxidation in spinal cords from sporadic amyotrophic lateral sclerosis patients. Brain Research 917(1): 97-104.

Sowell, J., Conway, H.M., Bruno, R.S., Traber, M.G., Frei, B. \& Stevens, J.F. 2005. Ascorbylated 4-hydroxy-2-nonenal as a potential biomarker of oxidative stress response. Journal of Chromatography B 827(1): 139-145.

Stadtman, E.R. \& Levine, R.L. 2003. Free radical-mediated oxidation of free amino acids and amino acid residues in proteins. Amino Acids 25: 207-218.

Stadtman, E.R. \& Levine, R.L. 2000. Protein oxidation. Annals of the New York Academy of Sciences 899: 191-208.

Stadtman, E.R. \& Berlett, B.S. 1997. Reactive oxygen-mediated protein oxidation in aging and disease. Chemical Research of Toxicology 10(5): 485-494.

Sun, G.Y., Horrocks, L.A. \& Farooqui, A.A. 2007. The roles of NADPH oxidase and phospholipases A2 in oxidative and inflammatoryresponses in neurodegenerative diseases. Journal of Neurochemistry 103(1): 1-16.

Tamagno, E., Parola, M., Guglielmotto, M., Santoro, G., Bardini, P., Marra, L., Tabaton, M. \& Danni, O. 2003. Multiple signaling events in amyloid $\beta$-induced, oxidative stressdependent neuronal apoptosis. Free Radical Biology and Medicine 35(1): 45-58.

Tan, M.S., Tan, L., Jiang, T., Zhu, X.C., Wang, H.F., Jia, C.D. \& Yu, J.T. 2014. Amyloid- $\beta$ induces NLRP1-dependent neuronal pyroptosis in models of Alzheimer's disease. Cell Death and Disease 5: e1382.

Uttara, B., Singh, A.V., Zamboni, P., \& Mahajan, R.T. 2009. Oxidative stress and neurodegenerative diseases: A review of upstream and downstream antioxidant therapeutic options. Current Neuropharmacology 7(1): 65-74.

Vassalle, C., Maffei, S., Boni, C. \& Zucchelli, G.C. 2008. Genderrelated differences in oxidative stress levels among elderly patients with coronary artery disease. Fertility and Sterility 89(3): 608-613.

Wan Ahmad, W.N., Sakri, F., Mokhsin, A., Rahman, T., Mohd Nasir, N., Abdul-Razak, S., Md Yasin, M., Mohd Ismail, A., Ismail, Z. \& Nawawi, H. 2015. Low serum high density lipoprotein cholesterol concentration is an independent predictor for enhanced inflammation and endothelial activation. PLoS One 10(1): e0116867.

Wang, Q., Tang, X.N. \& Yenari, M.A. 2006. The inflammatory response in stroke. Journal of Neuroimmunology 184(1-2): 53-68.

Wang, X., Pu, H., Ma, C., Jiang, T., Wei, Q., Zhang, C., Duan, M., Shou, X., Su, L., Zhang, J. \& Yang, Y. 2014. Adiponectin abates atherosclerosis by reducing oxidative stress. Medical Science Monitor: International Medical Journal of Experimental and Clinical Research 20: 1792-1800.

Wang, Z., Rhee, D.B., Lu, J., Bohr, C.T., Zhou, F., Vallabhaneni, H., de Souza-Pinto, N.C. \& Liu, Y., 2010. Characterization of oxidative guanine damage and repair in mammalian telomeres. PLoS Genetics 6(5): e1000951.

Ward, N.C., Hodgson, J.M., Puddey, I.B., Mori, T.A., Beilin, L.J. \& Croft, K.D. 2004. Oxidative stress in human hypertension: Association with antihypertensive treatment, gender, nutrition, and lifestyle. Free Radical Biology and Medicine 36(2): 226-232.

Warner, D.S., Sheng, H. \& Batinić-Haberle, I. 2004. Oxidants, antioxidants and the ischemic brain. The Journal of 
Experimental Biology 207: 3221-3231.

Wei, Y., Clark, S.E., Morris, E.M., Thyfault, J.P., Uptergrove, G.M.E., Whaley-Connell, A.T., Ferrario, C.M., Sowers, J.R. \& Ibdah, J.A. 2008. Angiotensin II-induced non-alcoholic fatty liver disease is mediated by oxidative stress in transgenic TG(mRen2)27(Ren2) rats. Journal of Hepatology 49(3): 417-428.

Winterbourn, C.C., Bonham, M.J.D., Buss, H., Abu-Zidan, F.M. \& Windsor, J.A. 2003. Elevated protein carbonyls as plasma markers of oxidative stress in acute pancreatitis. Pancreatology 3(5): 375-382.

Wu, L.L., Chiou, C.C., Chang, P.Y. \& Wu, J.T. 2004. Urinary 8-OHdG: A marker of oxidative stress to DNA and a risk factor for cancer, atherosclerosis and diabetics. Clinica Chimica Acta 339(1-2): 1-9.

Xu, Y., Zhang, J.J., Xiong, L., Zhang, L., Sun, D. \& Liu, H. 2009. Green tea polyphenols inhibit cognitive impairment induced by chronic cerebral hypoperfusion via modulating oxidative stress. The Journal of Nutritional Biochemistry 21(8): 741-748.

Yang, H., Song, Z., Yang, G.P., Zhang, B.K., Chen, M., Wu, T. \& Guo, R. 2014. The ALDH2 rs671 polymorphism affects post-stroke epilepsy susceptibility and plasma 4-HNE levels. PLoS One 9(10): e109634.

Yang, R-L., Li, W., Shi, Y-H. \& Le, G-W. 2008. Lipoic acid prevents high-fat diet-induced dyslipidemia and oxidative stress: A microarray analysis. Nutrition 24(6): 582-588.

Yasuhara, T., Hara, K., Sethi, K.D., Morgan, J.C. \& Borlongan, C.V.2007. Increased 8-OHdG levels in the urine, serum, and substantia nigra of hemiparkinsonian rats. Brain Research 1133(1): 49-52.

Yoon, J.H., Kim, J.Y., Park, J.K. \& Ko, S.B. 2015. Oxidative damage markers are significantly associated with the carotid artery intima-media thickness after controlling for conventional risk factors of atherosclerosis in men. PLoS
One 10(3): e0119731.

Zhang, S., Zhang, Z., Sandhu, G., Ma, X., Yang, X., Geiger, J.D. \& Kong, J. 2007. Evidence of oxidative stress-induced BNIP3 expression in amyloid beta neurotoxicity. Brain Research 1138: 221-230.

Zhang, W., Wang, T., Pei, Z., Miller, D.S., Wu, X., Block, M.L., Wilson, B., Zhang, W.,Zhou, Y., Hong, J.S. \& Zhang, J. 2005. Aggregated alpha-synuclein activates microglia: A process leading to disease progression in Parkinson's disease. FASEB Journal 19(6): 533-542.

Zhong, H. \& Yin, H. 2014. Role of lipid peroxidation derived 4-hydroxynonenal (4-HNE) in cancer: Focusing on mitochondria. Redox Biology 4C: 193-199.

School of Medicine

Walailak University, Nakhon Si Thammarat, 80161

Thailand

The Pathobiology of Cell and Tissue Research Group

Walailak University, Nakhon Si Thammarat, 80161

Thailand

*Corresponding author; email: spalipoch@hotmail.com

Received: 29 November 2013

Accepted: 24 June 2015 